\title{
Efektivitas Program Pendidikan Guru MIPA Kelas Bilingual Universitas Negeri Jakarta
}

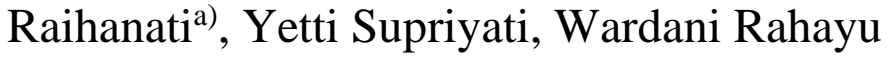 \\ Program Pascasarjana, Universitas Negeri Jakarta, Jalan Rawamangun Muka, Jakarta, 13220 \\ Email: a)raihanati57@gmail.com
}

\begin{abstract}
This research aims to determine the effectiveness of Bilingual Class Mathematics and Sciences Educational Teacher State University of Jakarta (PGMIPABI) State University of Jakarta. This research is evaluation program, conducted at Faculty of Mathematics and Sciences, State University of Jakarta, use Countenance Stake models. Based on the result data analysis and data interpretation formulated: (1) PGMIPABI Program at State University of Jakarta conducted professionally, with clear legal basis, and involve stakeholders; (2) PGMIPABI program at State University of Jakarta, conducted with support by lecturer staff, utilizing the integrated infrastructure management, so as meet the satisfaction by students; (3) PGMIPABI program of State University of Jakarta, produces MIPA teacher candidates with good performance and well received by bilingual school when a field study. Based on the result, can concluded the PGMIPABI State University of Jakarta was effective. Then researcher recommended this program will be continuous, but the Lecturer ability about teaching in English on mathematic and sciences will be improve.
\end{abstract}

Keywords: PGMIPABI, Evaluation Program, Stake Countenance Model

\begin{abstract}
Abstrak
Penelitian ini bertujuan untuk mengetahui efektivitas program pendidikan guru MIPA Kelas Bilingual (PGMIPABI). Penelitian yang dilakukan merupakan penelitian evaluasi program, yang dilakukan di Fakultas Matematika dan Ilmu Pengetahuan Alam Universitas Negeri Jakarta dengan menggunakan pendekatan Model Countenance Stake. Menggunakan angket, pedoman wawancara sebagai alat pengumpul data. Berdasarkan hasil analisis data dan interpretasi data dirumuskan kesimpulan sebagai berikut: (1) program PGMIPABI Universitas Negeri Jakarta direncanakan secara professional, dengan dasar hukum yang jelas, dan melibatkan stake holders; (2) Pelaksanaan PGMIPABI Universitas Negeri Jakarta didukung oleh tenaga pendidik, tenaga kependidikan, memanfaatkan sarana prasarana penunjang yang dikelola secara terpadu, sehingga memberikan kepuasan terhadap mahasiswa; namun masih sangat terbatas dosen yang menguasai kemampuan mengajar dengan pengantar bahasa inggris, (3) PGMIPABI Universitas Negeri Jakarta menghasilkan calon guru MIPA Bilingual dengan prestasi baik dan diterima dengan baik oleh sekolah bilingual di tempat mereka PPL (Program Pengalaman Lapangan). Dengan demikian dapat disimpulkan bahwa PGMIPABI sudah berjalan secara efektif. Peneliti merekomendasikan sebaiknya PGMIPABI dilanjutkan, dan perlu peningkatan kemampuan dosen menggunakan bahasa inggris dalam pembelajaran.
\end{abstract}

Kata-kata kunci: PGMIPABI, evaluasi Program, Model Stake Countenance 


\section{PENDAHULUAN}

Penelitian ini bertujuan untuk mengetahui efektivitas Program Pendiddikan Guru MIPA Bilingual (PGMIPABI) pada FMIPA Universitas Negeri Jakarta. Termasuk dalam penelitian evaluasi. Sesuai dengan pengertian evaluasi seperti yang disampaikan oleh Stuffebeam and Shinkfield yang menyatakan "evaluation is the systematic assessment of an object's merit, worth, probility, feasibility, safety, significance, and/or equity", (Stuffebeam 2007). Selanjutnya evaluasi adalah pemberian keputusan tentang nilai sesuatu yang mungkin dapat dilihat dari segi tujuan, gagasan, cara bekerja, pemecahan, metode, material, dan lain-lain yang memerlukan standar atau kriteria tertentu, (Sudjana 2002). Hasil evaluasi dapat dimanfaatkan sebagai bahan pertimbangan dalam mengambil keputusan, Arikunto S (2009) "Evaluasi merupakan kegiatan mengumpulkan informasi tentang sesuatu, yang selanjutnya informasi tersebut dianalisis untuk kemudian digunakan untuk mengambil keputusan."

Penelitian ini termasuk evaluasi program, sesuai dengan tujuan penelitian seperti disampaikan oleh Kamil M (2010), evaluasi program bertujuan menyediakan masukan bagi pengambil kebijakan tentang perencanaan, kelanjutan, perluasan, penghentian, modifikasi program, maupun dukungan terhadap kelangsungan dan penyelesaian program, serta penggunaan dan pengembangan landasan ilmiah yang mendasari proses evaluasi. Menurut Arikunto dan Jabar (2010) terdapat tiga hal di dalam program yang menjadi sasaran evaluasi program, yaitu: 1) realisasi atau implementasi suatu kebijakan; 2) terjadi dalam waktu yang relatif lama, bukan kegiatan tunggal, tapi jamak berkesinambungan; dan 3) terjadi dalam organisasi yang melibatkan sekelompok orang.

Stepphen Isaac dalam Arikunto (2010) membedakan empat ragam model evaluasi, yaitu: 1)berorientasi pada tujuan (goal oriented); 2)berorientasi pada keputusan (decision oriented); 3)berorientasi pada kegiatan dan orang-orang yang menanganinya (transactional oriented); dan 4)berorientasi pada pengaruh dan dampak program (research oriented). Stake, seperti dikutip oleh Kamil menyatakan evaluasi program sebagai kegiatan untuk merespon suatu program yang telah, sedang, ataupun akan dilaksanakan.

Program Pendiddikan Guru MIPA Bilingual (PGMIPABI) Universitas Negeri Jakarta merupakan salah satu program pendidikan, dengan ciri seperti disebutkan oleh Soekartawi (199) bahwa setiap program pendidikan memerlukan dana, mempunyai tujuan yang spesifik, atau target yang ingin dicapai berdasarkan sasaran tertentu, memerlukan aktivitas tenaga, dan dilaksanakan dalam waktu tertentu. Stake, seperti dikutip oleh Kamil menyatakan evaluasi program sebagai kegiatan untuk merespon suatu program yang telah, sedang, ataupun akan dilaksanakan. Penilaian program pendidikan berorientasi langsung pada kegiatan program dan untuk merespon pihak yang membutuhkan informasi.

Evaluasi program pendidikan mempunyai peran sangat penting untuk menilai keberhasilan suatu program pendidikan. Menurut Worthen dan Sanders seperti dikutip oleh Setiadi, Ghani, dan Suyatno (2006), bahwa peranan evaluasi program pendidikan secara formal adalah : 1) menyiapkan dasar membuat keputusan dan kebijakan; 2) melakukan asesmen kepada prestasi siswa; 3) mengevaluasi kurikulum; 4) melakukan akreditasi sekolah; 5) memonitor pengeluaran dari dana masyarakat; dan 6) memperbaiki materi program pendidikan.

Program PGMIPABi memiliki karakteristik-karakteristik sebagai berikut: 1) Memenuhi Standar Nasional Pendidikan; 2) Sekurang-kurangnya 16 mata kuliah bidang MIPA (di luar mata kuliah bahasa Inggris) menggunakan bahan ajar dan pengantar bahasa Inggris; 3) Proses pembelajaran berpusat pada mahasiswa; 4) Proses pembelajaran menggunakan Information Comunication and Technology (ICT); 5) Memiliki Standar Kompetensi Lulusan (SKL) yang diperkaya dengan standar kompetensi lulusan pendidikan guru MIPA di negara-negara maju; 6) Menghasilkan lulusan yang mampu menyusun kurikulum, silabus, RPP, dan bahan ajar, dan instrumen penilaian dalam bahasa Inggris; 7) Evaluasi pembelajaran dilaksanakan secara berkualitas dan dalam bahasa Inggris; dan 8)Memperkenalkan budaya internasional dan memfasilitasi internalisasi nilai-nilai budaya yang positif (Widoyoko 2013 \& Rumah Pendidikan 2011). Sesuai dengan karakteristik dari program PGMIPABI, pada penelitian ini dipilih Countenance Evaluation Model yang dikembangkan oleh Stake. Stake membedakan tiga fase dalam evaluasi program yaitu: 1)Persiapan atau pendahuluan (antecendents), 2)Proses/transaksi (transaction-processes), 3)Keluaran atau hasil (outcomes, output).

e-Jurnal: http://doi.org/10.21009/1 


\section{METODE}

Pendekatan yang dipilih di dalam penelitian evaluasi ini adalah pendekatan berorientasi pada tujuan (goal oriented) (Tayibnapis 2008). Penelitian ini merupakan evaluasi program menggunakan metode study kasus (case studies), dimana penelitian difokuskan pada satu fenomena saja yang dipilih dan ingin dipahami secara mendalam, dengan mengabaikan fenomena-fenomena lainnya, (Sukmadinata 2010). Model evaluasi program yang dipilih pada penelitian ini adalah Countenance Evaluation Model, dikembangkan oleh Stake. Desain penelitian disajikan pada matriks dalam GAMBAR 1.

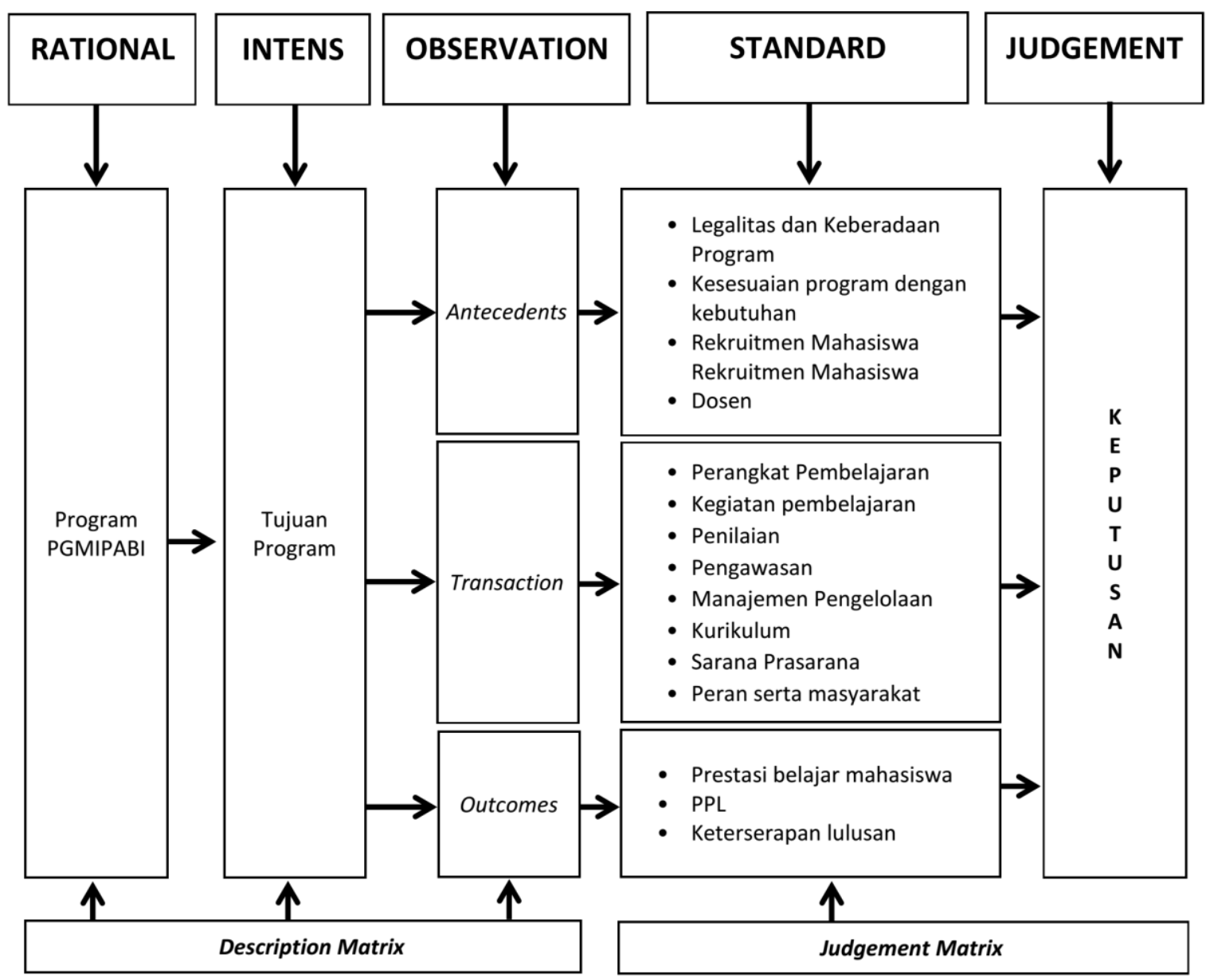

GAMBAR 1. Desain Penelitian Evaluasi Program Penyelenggaraan PGMIPABI UNJ.

\section{HASIL DAN PEMBAHASAN}

\section{Perencanaan atau Pendahuluan (Antecendence)}

Menurut survey yang dilakukan didapat informasi bahwa perencanaan dimulai dengan rancangan program berupa proposal yang disampaikan ke Direktorat Pendidikan Tinggi pada tahun 2009. Di dalam proposal tersebut tertera dasar hukum, kompetensi lulusan, rekruitmen, kurikulum, sarana prasarana, tenaga pengajar, dan penunjang pelaksanaan program. Program dilaksanakan mulai tahun ajaran 2009-2010 atas dasar izin dari Direktorat Jendral Pendidikan Tinggi. Jadi program PGMIPABI memiliki legalitas atau dasar hukum yang jelas. Program ini dibuka untuk memenuhi permintaan tenaga guru MIPA yang mampu mengajar di kelas internasional dan Bilingual. Menurut pengakuan mahasiswa, mereka memperoleh informasi tentang PGMIPABI dan melakukan pendaftaran melalui berbagai media, yaitu: online, leflet, spanduk, kerjasama dengan dinas pendidikan dan sekolah, serta melibatkan civitas akademika. Setelah lulus ujian tulis mereka mengikuti tes wawancara dengan pengantar bahasa Inggris, tes wawancara ini tidak dilakukan terhadap mahasiswa reguler. Dengan 
demikian dapat diartikan bahwa rekruitmen mahasiswa dilakukan dengan persyaratan khusus. Tenaga dosen yang dimiliki oleh FMIPA Universitas Negeri Jakarta memiliki kualifikasi minimal Magister, dan lebih dari 50\% tenaga dosen berpendidikan Doktor baik dari dalam maupun luar negeri. Jadi untuk tenaga dosen sudah memenuhi ketentuan yang ditetapkan oleh DIKTI tentang persyaratan dosen.

\section{Pelaksanaan Program atau Transaction}

Berdasarkan survey dan angket dengan responden mahasiswa dan dosen didapatkan informasi bahwa separuh dari mata kuliah untuk PMIPABI ditulis dalam bahasa inggris, di bawah $30 \%$ dosen mengajar dengan pengantar bahasa inggris baik saat mengajar, tugas, maupun ujian. Hampir $40 \%$ dosen mengajar menggunakan campuran bahasa Inggris dan bahasa Indonesia, dan sisanya menggunakan bahasa Indonesia. Penilaian yang digunakan adalah penilaian otentik yang menilai proses dan hasil perkuliahan. Menurut mahasiswa mereka merasa puas dan siap mengajar di kelas Bilingual, karena Praktik Keterampilan mengajar sudah mereka lakukan pada kelas bilingual. Pengawasan internal telah dilakukan oleh universitas dengan melibatkan Lembaga Penjaminan Mutu UNJ, sehingga tingkat ketercapaian kurikulum dan kepuasan mahasiswa dipantau secara berkesinambungan dan dilaporkan ke program studi setiap akhir semester. Menurut dosen setiap akhir semester mereka menerima hasil monitoring program dari LPM dan menjadi umpan balik untuk perkuliahan semester berikutnya.

Lebih dari $80 \%$ mahasiswa mengaku sarana prasarana seperti laboratorium, perpustakaan, ruang kuliah, bengkel, dan sarana prasarana lainnya sangat memadai dan mereka merasa puas dengan tata kelola sarana prasarana yang dilakukan oleh FMUPA UNJ. Mahasiswa juga yakin bahwa dengan sarana prasarana yang dimiliki oleh FMIPA UNJ, mereka bisa mencapai kompetensi sebagai guru MIPABI sesuai dengan program studi mereka. Karena pemanfaatan semua sarana prasaran perkuliahan cukup fleksibel. Dalam pelaksanaan program PGMIPABI dilakukan MoU dengan Dinas pendidikan, sejumlah SMA/SMP internasional dan yang mengelola kelas bilingual. Juga dilakukan kerjasama dengan badan atau lembaga terkait seperti PPIPTEK di Taman Mini Indonesia Indah. Orang tua/ wali mahasiswa dilibatkan dalam hal dana pendidikan. Sebagian dana pelaksanaan program dibebankan kepada orang tua mahasiswa, berupa SPP dan DPP.

\section{Outcomes}

Pada saat penelitian ini dilakukan sudah dua angkatan mahasiswa kelas Bilingual yang mengikuti kuiah delapan semester atau hampir 90\% mahasiswa angkatan pertama sudah menyelesaikan studi. Jadi masa studi mereka 4-5 tahun. Dengan IPK rerata 3,4 dengan kategori sangat memuaskan.

Menurut responden mahasiswa, mereka melakukan Praktik Keterampilan Mengajar di sekolah internasional dan di sekolah yang memiliki kelas Bilingual. Mereka diterima dengan baik dan diberi kepercayaan untuk mengajar di kelas Bilingual oleh sekolah tempat mereka melakukan praktik tersebut. Seluruh peserta PPL berhasil meraih predikat sangat baik. Belum dilakukan tracer study sehingga peneliti belum menapatkan informasi tentang keterserapan lulusan.

\section{SIMPULAN}

Berdasarkan hasil dan pembahasan yang telah disampaikan dapat disimpulkan bahwa Perencanaan PGMIPABI, pelaksanaan, dan outcomes sudah sesuai dengan rencana dan ketentuan perundangan yang berlaku. Sudah melibatkan stake holders, dan sudah memberikan kepuasan kepada mahasiswa. Memberikan hasil berupa lulusan dengan IPK rerata sangat memuaskan. 


\section{KEPUSTAKAAN}

Daniel L Stuffebeam and Anthony J. Shinkfield, Evaluation Theory, Models, and Aplication, San Francisco: Jossey-Bass, 2007.

Nana Sudjana, Penilaian Hasil Proses Belajar Mengajar, Bandung: Remaja Rosdakarya, 2002.

Suharsimi Arikunto, Dasar-dasar Evaluasi Pendidikan, Jakarta: Bumi Aksara, 2009.

Mustofa Kamil, Model Pendidikan dan Pelatihan, Bandung: Alfabeta, 2010.

Suharsimi Arikunto dan Cepi Safrudin Abdul Jabar, Evaluasi program Pendidikan, Pedoman teoritis dan Praktis bagi mahasiswa dan Praktisi Pendidikan, Jakarta: Bumi Aksara, 2010.

EVALUASI\%20PROGRAM/Model\%20Evaluasi\%20Program_2.htm, Model Evaluasi Program, Selasa, 01 Juni 2010.

Soekartawi, Monitoring dan Evaluasi Proyek Pendidikan, Jakarta: Dunia Pustaka Jaya, 1995.

Hari Setiadi, Abd. Rahman A. Ghani, dan Suyatno, Evaluasi pendidikan: Konsep dan Aplikasi, Jakarta: Uhamka Press, 2006.

S. Eko Putro Widoyoko, Evaluasi Program Pembelajaran, Yogyakarta: Pustaka Pelajar, 2013.

Rumah pendidikan "the home of knowledge" in Evaluasi Pembelajaran Rabu, Maret 2011.

Farida Yusuf Tayibnapis, Evaluasi program dan Instrumen Evaluasi untuk Program Pendidikan dan Penelitian, Jakarta: Rineka Cipta, 2008.

Nana Saodih Sukmadinata, Metode Penelitian Pendidikan, Bandung: PT. Remaja Rosdakarya, 2010. 
